\title{
FIELDS OF IMPLEMENTATION OF THE TEACHER'S EDUCATIONAL FUNCTIONS
}

\author{
Venelin Terziev ${ }^{1}$, Margarita Bogdanova ${ }^{2}$, Marin Georgiev ${ }^{3}$, Denis Solovev ${ }^{4}$, Plamen \\ Bogdanov $^{5}$ \\ ${ }^{1}$ Full Member of the Russian Academy of Natural History, Professor, Eng., D.Sc. (National \\ Security), D.Sc. (Economics), D.Sc. (Social Activities), Ph.D. \\ Georgi Rakovski Military Academy, Sofia, Bulgaria \\ University of Rousse, Rousse, Bulgaria \\ Russian Academy of Natural History, Moscow, Russia \\ terziev@skmat.com \\ ${ }^{2}$ Professor, Ph.D., Tsenov Academy of Economics, Svishtov, Bulgaria, \\ m.bogdanova@uni-svishtov.bg \\ ${ }^{3} \mathrm{Ph} . \mathrm{D}$, Kaneff University Hospital, Rousse, Bulgaria, clementon@abv.bg \\ ${ }^{4}$ Professor, Ph.D., Far Eastern Federal University (FEFU), Vladivostok, Russian Federation, \\ solovev.db@dvfu.ru \\ ${ }^{5}$ Ph.D., University of Library Studies and Information Technologies (ULSIT), Sofia, Bulgaria, \\ bogdanovpn@abv.bg
}

\begin{abstract}
The present work seeks to answer which are the appropriate tools for an effective organization for carrying out a creative learning process In the aggregate of complex social and pedagogical functions performed by the teacher, the education of adolescents occupies the largest share. This is where the teacher spends most efforts, in which his qualities of a teacher and educator stand out most clearly. Through his activity in the learning process, the teacher is the one who mostly contributes to the development of the students, integrates them into the rich cognitive experience of mankind, prepares them for inclusion in the various fields of social and economic life.
\end{abstract}

Keywords: approaches, governance, education, processes, changes.

\section{INTRODUCTION}

With the changes that took place in the first decade of the 21st century, in view of Bulgaria's membership in the European Union, the management of the learning processes is of utmost importance for its quality. The management of this process is becoming increasingly important as new educational and information technologies are introduced. Significant importance in this process have the individual characteristics and abilities of the students, their adaptation to school environment in order to master a maximum amount of knowledge and to strengthen skills for future realization. 
Today, when talking about modern education, all of us imagine a well-equipped classroom, new technologies and opportunities for interactive teaching models, computers, tablets and students working with them. Practically, in most schools we can notice attempts for modernization of the physical school environment with new modern technologies, as this still remains a vague attempt by which educators are trying to respond to the dynamical and rapidly changing needs and expectations of students.

In the aggregate of complex social and pedagogical functions performed by the teacher, the education of adolescents occupies the largest share. This is where the teacher spends most efforts, in which his qualities of a teacher and educator stand out most clearly. Through his activity in the learning process, the teacher is the one who mostly contributes to the development of the students, integrates them into the rich cognitive experience of mankind, prepares them for inclusion in the various fields of social and economic life (Terziev, Bankova, Dacheva, 2019-a).

\section{FIELDS OF IMPLEMENTATION OF THE TEACHER'S EDUCATIONAL FUNCTIONS}

In the aggregate of complex social and pedagogical functions performed by the teacher, the education of adolescents occupies the largest share. This is where the teacher spends most efforts, in which his qualities of a teacher and educator stand out most clearly. Through his activity in the learning process, the teacher is the one who mostly contributes to the development of the students, integrates them into the rich cognitive experience of mankind, prepares them for inclusion in the various fields of social and economic life (Terziev, Dimitrovski, Pushova, Georgiev, Solovev, 2020).

Motivation and attitude. The second significant field in which the teacher deploys his or her diverse activity (fig. 1), is the sphere of motivation and attitude of adolescents towards various facts and phenomena in social reality. The teacher forms the personality's relationships and behavior's motives, both in and out of teaching. He offers and justifies standards of socially appropriate behavior. The appearance of each person depends to a large extent on the nature of the motives behind it. This area of teaching is too delicate, the relationship between impacts and outcomes is difficult to discover, but its existence is undeniable. Unlike education, the degree of uncertainty here is extremely high, and that's why this side of teacher preparation is often ignored.

Social control over the class is presented through the pedagogic authority which the teacher exercises in different situations. This activity field in which the teacher implements one part of his functions is significant in impact over the students' behavior and the consequences for their general development. Usually this area is thought to be exhausted with discipline, but it is not. School-based social control assigned to teachers has significantly more complex functions than discipline. Discipline is one of the essential components of social control exercised by teachers, but is not limited to it. The types of control exercised by different teachers vary too much. This area has its own social and pedagogical technology, which, unfortunately, is quite poorly developed.

Among the factors that often hinder the implementation of teacher functions, the most common are:

- Overload of the professional role of the teacher - the teacher has to fulfil many tasks to meet the many expectations for him;

- The complexity of the role and especially the unpredictability of the results of its implementation - each teacher is placed in a unique and professional environment that is constantly changing. From there comes the unpredictability of the results;

- Polyexpectations of teacher - the teacher shall meet the expectations of various groups of people - of their colleagues, pupils and their parents, of the school's management. The teacher may not always harmonize the group expectations of the different categories.

The teacher combines in a complicated complex its main functions - executive, interactive, social and organizational. His success in this case depends on: the knowledge he has; his ability to use them; his attitude towards his own work and towards people related with it (including towards children) - i.e. in order to assess yourself as a teacher, you have to evaluate:

- Your affective characteristics;

$\checkmark$ Your motivation for selecting a teacher's career;

$\checkmark$ Your interest towards it;

$\checkmark$ Your ideas of how the profession should look like;

$\checkmark$ Your personal attractiveness for others; 
$\checkmark$ Your skills to build friendly relationships and attitude of mutual respect;

$\checkmark$ Other people's reactions to you;

$\checkmark$ Your social intelligence;

- Your cognitive features:

$\checkmark$ Your level of general education preparation;

$\checkmark$ Your desire for continuous learning;

$\checkmark$ Your intellectual curiosity;

$\checkmark$ Your skills to introduce novelties;

$\checkmark$ Your intellectual preferences towards a particular school subject;

$\checkmark$ Your desire to gain professional proficiency;

$\checkmark$ Your specialized knowledge in the subject.

The tasks that a teacher has to perform as an educator, as a teacher, and as a class teacher are quite diverse. Exploring the students - without this, the teacher would not be able to make the right decisions. The teacher examines the student in a natural setting and takes into account the individual and age changes, examines the student thoroughly, in all its acts, explores the living conditions in the family of each student, examines the student's attitude to people around him, to learning and work, etc. K. Platonov recommends the class teacher to examine two groups of personality properties and qualities (Fig.1-2):

- Peculiarities of the personality's general traits and qualities - orientation, moral qualities, character, temperament and special features;

- Peculiarities of the individual mental processes - of perception, attention, psychomotor peculiarities, thinking, memory, emotional and volitional characteristics.

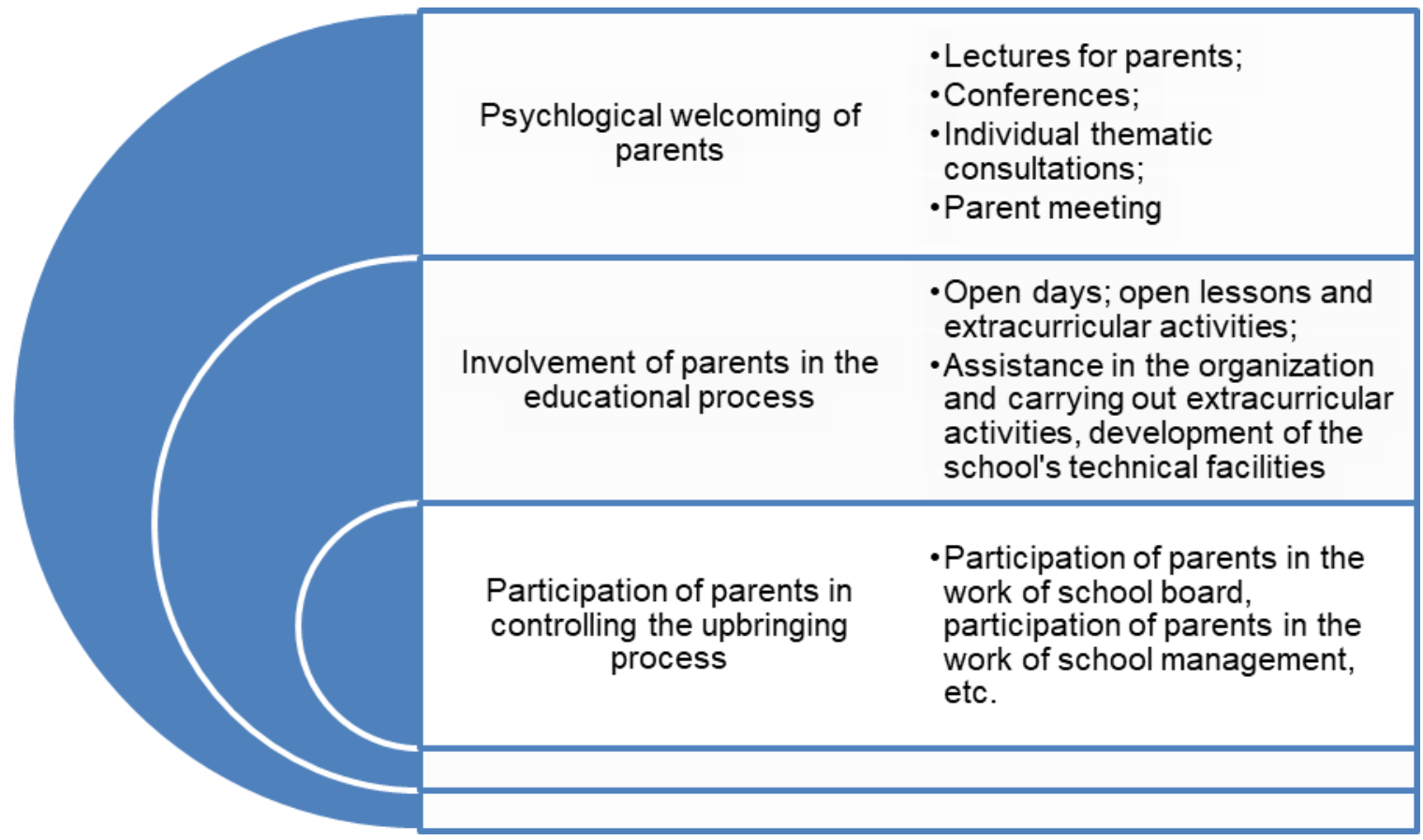

Fig. 1. Main directions of teacher-parents collaboration.

The teacher has to examine also the relationships (unity, organization, type of public opinion, humanity in relations, etc.) between the students in the class. For this purpose, various methods may be used: observation, studying the results of creative work, creating educational situations, pedagogical consultations, etc. Building humane relationships between the students in the class, showing them the perspectives of interest and meaningful co-existence, directing the students not to accomplish external tasks, but to selforganize and self- initiate activities.

Emphasizing the efforts of the teacher to form a culture of behaviour, to enrich the common culture of 
students, to foster a love for nature.

Establishing a responsible attitude towards learning, towards their future professional development, supporting the awareness of the unity of public need and personal importance of high professional qualification and education.

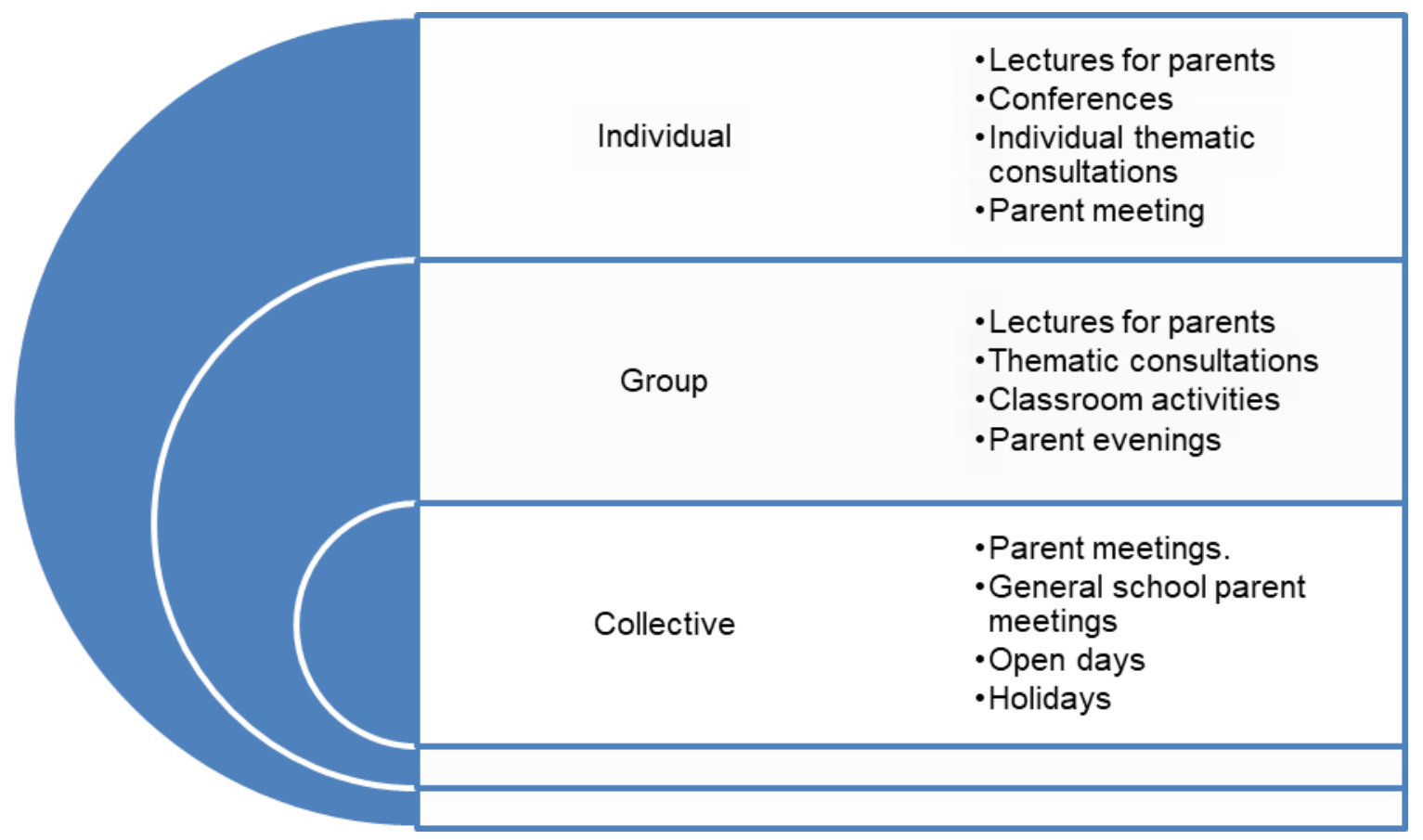

Fig. 2. Types of school-familty relations.

Setting the foundation of personality's traits, attitudes, beliefs, behaviours that shape her / his image as a good citizen of society.

A major component of a teacher's pedagogical proficiency and creativity are his or her professional skills. Some authors (M. A. Verb, V. G. Kutsenko) refer to them professional vigilance, optimistic forecast, organizational skills, adequate response and pedagogical intuition. Pedagogical skills as a component of teachers' pedagogic proficiency play an important role in improving the quality of the educational process. An essential component of pedagogical proficiency and creativity is the teacher's intuition. The pedagogic intuition, the teacher's ability to foresee and anticipate events, is based on his knowledge and experience. Intuition and pedagogic experience are mastered by teachers gradually and continuously. Their effectiveness is related to the overall development of the teacher's personality, his ability to monitor and analyse the actions and overall behaviour of his students. The degree of educational impact is an important part of pedagogic proficiency. Pedagogic technique is a major component of pedagogic proficiency. The content of this concept includes various techniques and practical skills of the teacher - look, facial expressions, gestures, gait, voice production. Educator's oral speech is distinguished by clarity, logical consistency, expressiveness and emotional colour. Voice production has a strong educational charge. 'I became a real master' - says A. S. Makarenko (Makarenko, 1958), when I learned to say 'come here' with 15-20 different tones, when I learned to make 20 different facial expressions of face, figure and voice. Researches show that shouting tone is not well accepted by students. The lower but soft and expressive tone has a greater influence on the emotional and intellectual part of their consciousness. Sometimes educational situations require the teacher to raise his voice, to show the students that he is angry and dissatisfied. Through gestures the educator expresses his feelings and moods. Gestures can help for the creation of an upbeat atmosphere in the classroom. Essential elements in the pedagogical technique are the gesture, the gait, the teacher's ability to stand, to always be tight, to express optimism and cheerfulness. The mastering of pedagogic technique and display of creativity enables the teacher to express his personality more fully, to overcome the monotony, the pattern, the boredom in his activity and to increase the educational influence on the students. "The teaching skills strongly contribute for this objective, the strongest being the skill to vary the communication approaches and equipment, 'the openness' in the character and performance of the teacher (and also the students), which leads to honesty in the relationship, the preparedness and aspiration to empathy (empathic abilities)". The regular interaction between teacher and parents is of great importance. However, its implementation is very restricted and reduced to its formal 
outline - for reporting purposes only. And relationships are essential, first and foremost, for a more complete and accurate understanding of children, revealing their own individuality and its expressions, their problems as students, classmates and friends) (1993-1999; 1993a; Radev, Mihaylova, Terzieva, Stoyanovich, 2014-a; Mihaylova, 2015; Popov, Aleksandrova, Garov, Mihaylova, 2016; Balkanska, Garov, Trendafilova, Mihaylova, Georgiev, 2017).

\section{CONCLUSION}

There are occupations, in which the identification with certain individuals and environment becomes a material measure of their implementation and efficiency. In this line of occupations, maybe the actor's profession is the brightest one where the identification comprises also invisible details of the characters so that they can be convincing in the transformation. The teacher's occupation is of the same type, because the teaching and educational interactions with students, as a central and leading moment in its implementation, are not only to understand each other better. In this example the tasks go further - by understanding the students they should progress in their development, should provide them with relevant conditions for learning, for their personal comprehensive accomplishment (Terziev, Stoilova, 2019b-c).

\section{REFERENCE LIST}

Terziev, V., Bankova, D., Dacheva, I. (2019). Approaches in governing the educational processes in schools. // XXII International Scientific Conference: The power of knowledge (11-13.10.2019), Kavala, Greece, Institute of Knowledge Management, Skopje, 34, 2019, 2, pp. 311-316, ISSN 1857-923X (for eversion), ISSN 2545 - 4439 (for printed version).

Terziev, V., Bankova, D., Dacheva, I. (2019a). Theoretical underpinning of the problems related to pedagogical excellence and pedagogical creativity in the initial stage of school education. // XXII International Scientific Conference: The power of knowledge (11-13.10.2019), Kavala, Greece, Institute of Knowledge Management, Skopje, 34, 2019, 2, pp. 411-417, ISSN 1857-923X (for eversion), ISSN 2545 - 4439 (for printed version).

Terziev, V., Dimitrovski, R., Pushova, L., Georgiev, M., Solovev, D.(2020). Change management and digital age training. // Proceedings of INTCESS 2020- 7th International Conference on Education and Social Sciences 20-22 January, 2020 - DUBAI (UAE), International Organization Center of Academic Research, Istanbul, Turkey, 2020, pp. 730-738, ISBN: 978-605-82433-8-5.

Makarenko, L.,S. (1958). Soch . v semi pomoh., M, izd. APN, 1958 str. 235 (Макаренко, Л.,С. (1958). Соч . в семи помох., М, изд. АПН, 1958 стр. 235).

Rossiyskaya pedagogicheskaya entsiklopediya (1993-1999). v 2 t. / gl. red. V.V. Davaydov, M., 1993-1999 (Российская педагогическая энциклопедия: в 2 т. / гл. ред. В.В. Давыдов, М., 1993-1999).

Rossiyskaya pedagogicheskaya entsiklopediya (1993a). М.: Bolyshaya ros. entsikl., 1993 (Российская педагогическая энциклопедия, М.: Большая рос. энцикл., 1993).

Radev, E., Tsv., Mihaylova, A., Terzieva, Al., Stoyanovich. (2014). Profesionalizam-profesionalen moral. // „Kontakt 2014“ ot 27 yuni 2014, Sofiya, Izdatelstvo TEMPO-Sofiya, s. 203-206, ISSN 1313-9134 (Радев, Е., Цв., Михайлова, А., Терзиева, Ал., Стоянович. Професионализъм-професионален морал. // „Контакт 2014“ от 27 юни 2014, София, Издателство ТЕМПО-София, с. 203-206, ISSN 1313-9134).

Radev, E., Tsv. Mihaylova, A. Terzieva, Al., Stoyanovich. (2014a). Sotsiologicheski aspekti na zdravniya menidzhmant. // „Kontakt 2014“ ot 27 yuni 2014, Sofiya, Izdatelstvo TEMPO-Sofiya, s. 365-368 ISSN 1313-9134 (Радев, Е., Цв. Михайлова, А. Терзиева, Ал. Стоянович. Социологически аспекти на здравния мениджмънт. // „Контакт 2014“ от 27 юни 2014, София, Издателство ТЕМПО-София, с. 365-368 ISSN 1313-9134).

Mihaylova, Tsv. (2015). Neobhodimosty v lidere i liderskih kachestvah, formay i metoday sotsialynoy rabotay v razlichnayh sferah zhiznedeyatelynosti. // Ulan-Ude, Izdatelystvo VSGUTU, 2015 (Михайлова Цв. Необходимость в лидере и лидерских качествах, формы и методы социальной работы в различных сфрерах жизнедеятельности. // Улан-Удэ, Издательство ВСГУТУ, 2015). 
Popov, T., M., Aleksandrova, Sv., Garov, Tsv., Mihaylova. (2016). Izkustvoto vav vazpitatelnata deynost. // Nauchni statii, Trideset i osma nauchno-tehnologichna sesiya INGA sbornik izd. «TEMTO» Sofiya, 28. 10. 2016, str.9-15 (Попов, Т., М., Александрова, Св., Гаров, Цв., Михайлова. Изкуството във възпитателната дейност. // Научни статии, Тридесет и осма научно-технологична сесия ИНГА сборник изд. «ТЕМТО» София, 28. 10. 2016, стр.9-15).

Balkanska, P., Sv., Garov, A., Trendafilova, Tsv., Mihaylova, N., Georgiev. (2017). Podhodi za ekipna efektivnost. // 39 Nauchno-tehnologichna sesiya „Grazhdanskata ideya v deystvie” Kontakt 2017, 30 yuni 2017g., Sofiya. Izd. Temto. 199-204 (Балканска, П., Св., Гаров, А., Трендафилова, Цв., Михайлова, Н., Георгиев. Подходи за екипна ефективност. // 39 Научно-технологична сесия „Гражданската идея в действие” Контакт 2017, 30 юни 2017г., София. Изд. Темто. 199-204).

Terziev, V., Stoilova, M. (2019b). Analysis of the system of school education. Strategy settlement process. // 21 st International scientific conference: The teacher of the future, Budva, Montenegro, (0709.06.2019), Institute of knowledge management - Skopje, Macedonia, 31, 2019, 6, pp. 1851-1857, ISSN 1857-923X (for e-version), ISSN 2545 - 4439 (for printed version).

Terziev, V., Stoilova, M. (2019c). Experience of SWOT analysis in the system of the Bulgarian education. // 21 st International scientific conference: The teacher of the future, Budva, Montenegro, (0709.06.2019), Institute of knowledge management - Skopje, Macedonia, 31, 2019, 6, pp. 1887-1893, ISSN 1857-923X (for e-version), ISSN 2545 - 4439 (for printed version). 